\title{
The effect of duplex surface treatment on erosion performance of QRO 90 Supreme steel
}

\author{
MUMIN TUTAR, HAKAN AYDIN*(D) and ALI DURMUS \\ Faculty of Engineering, Department of Mechanical Engineering, Bursa Uludag University, 16059 Görükle, \\ Bursa, Turkey \\ e-mail: mmnttr@gmail.com; hakanay@uludag.edu.tr; adurmus@uludag.edu.tr
}

MS received 15 March 2018; revised 14 December 2018; accepted 8 January 2019; published online 25 March 2019

\begin{abstract}
In this study, $\mathrm{CrN}$ and TiAlN thin films were deposited on plasma-nitrided QRO 90 Supreme hot work tool steel by physical vapor deposition process and analysed with regard to their erosion performance under hydro-abrasive erosion conditions. The as-received specimens were quenched to room temperature from $1050^{\circ} \mathrm{C}$ and tempered gradually at $605^{\circ} \mathrm{C}$ for $2 \mathrm{~h}$ and at $560^{\circ} \mathrm{C}$ for $4 \mathrm{~h}$. These specimens were plasma-nitrided for $10 \mathrm{~h}$ at $500^{\circ} \mathrm{C}$ at a pressure of $250 \mathrm{~Pa}$ in a gas mixture of $80 \% \mathrm{~N}_{2}+20 \% \mathrm{H}_{2}$ and then coated with TiAlN or $\mathrm{CrN}$ coatings by cathode arc evaporation. The specimens were characterized by metallographic techniques, SEM, EDS and micro-hardness test. Plasma nitriding and duplex surface treatments significantly increased the hardness of the specimens and thus significantly reduced the erosion of the specimens. The hardnesses on the surface of plasma-nitrided, CrN-deposited and TiAlN-deposited QRO 90 steels were $1092 \mathrm{HV}_{0.025}, 2436$ $\mathrm{HV}_{0.025}$ and $3578 \mathrm{HV}_{0.025}$, respectively. TiAlN-coated specimens were about 17-fold harder than the as-received specimens and over 3-fold harder than the plasma-nitrided specimens. The erosion resistance of $\mathrm{CrN}$-coated specimens was increased by a factor of 3.6 and 1.5 compared with that of the as-received and plasma-nitrided specimens, respectively. A brittle fracture phenomenon was observed on the eroded surface of the duplex-treated specimens while a ductile material removal was observed on the as-received and the tempered specimens. The plasma-nitrided specimens showed a mixed behaviour of ductility and brittleness.
\end{abstract}

Keywords. QRO 90 Steel; duplex surface treatment; erosive wear.

\section{Introduction}

The phenomenon of hydro-abrasive erosion occurs as a result of repeated impacts of small solid particles carried by a liquid at high velocity. The particles damage the surface of the target material depending on the impact conditions [1]. The intensity of hydro-abrasive erosion depends upon the eroding particle parameters such as particle size, shape, hardness and concentration, the operating conditions such as velocity of water, impingement angle, etc. and the base material properties [2-8]. The predominant erosion mechanism is the direct fracture for the hard and brittle target materials; however, for the ductile target materials, the mechanism of plastic deformation, micro-cutting, plowing and low-cycle fatigue can be effective [9-11]. Generally, hydro-abrasive erosion with hard particles can be identified as abrasive wear [7]. Padhy and Saini [7] stated that the actual mechanism of erosive wear was not fully understood and the most common expression for the erosive wear was based on experimental experiences.

*For correspondence
Erosion due to impact of hard and abrasive particles may be very important for the service life of equipment used in some industries such as in hydro-turbines, mining, metallurgy and crude oil drilling. The use of steels in these industries inevitably involves surface modification treatments. Among various surface modification techniques, thin, hard and wear-resistant metallic nitride coatings, such as TiN, TiCN, TiAlN, $\mathrm{ZrN}, \mathrm{CrN}$ and $\mathrm{Cr}_{2} \mathrm{~N}$, fabricated by physical vapor deposition (PVD), are commonly used to improve the surface characteristics of steels in some tribological applications under extreme conditions [12-15]. Also, to enhance the load bearing capacity of the substrate, a diffusion-based surface treatment such as plasma nitriding process that can produce fairly thick surface layers with high load bearing ability is carried out prior to hard coating (duplex surface treatment) [15-18]. Hence, a smooth hardness transition, which provides better performance, could be obtained. Jianxin et al [19] deposited four nitride coatings (CrN, ZrN, CrAlN and TiAlN) on YT15-cemented carbide by cathode arc evaporation technique and showed that the coatings with $\mathrm{Al}$ (CrAlN and TiAlN) exhibited higher erosion wear resistance over those without $\mathrm{Al}(\mathrm{CrN}$ and TiN). Laguna-Camacho et al [20] studied solid particle 
erosion behaviour of TiN coating on AISI 4140 steel and reported that TiN coating showed its maximum erosion rate at $30^{\circ}$. Cabo et al [21] stated that the erosion resistance of the nitrided precipitation-hardened stainless steel at $500^{\circ} \mathrm{C}$ was the highest. Hasan et al [22] reported that the plasmanitrided H13 die steel exhibited higher erosive wear resistance, but TiN, duplex TiN and TiAlCN showed higher roughness and lower erosive wear resistance. Allenstein et al [23] found that the plasma-nitrided layer obtained at $5 \% \mathrm{~N}_{2}\left(+95 \% \mathrm{H}_{2}\right)$ led to a better cavitation erosion resistance of the CA-6NM martensitic stainless steel. Panjan et al [24] showed that the erosive wear of duplex-treated die-casting tools was smaller than that of plasma nitrided.

QRO 90 Supreme steel is a high-performance, chromium-molybdenum-vanadium-alloyed hot work tool steel, which is characterized by excellent high temperature strength and hot hardness, very good temper resistance and good heat treatment properties [25]. QRO 90 Supreme steel is used for cores, core pins, inserts and small- to mediumsized dies, shot sleeves, moving parts for aluminium, brass and copper die casting [25]. QRO 90 Supreme hot work tool steel is commonly subjected to nitriding and nitrocarburizing to improve the wear and erosion resistance. Duplex surface treatments of QRO 90 Supreme steels may also further improve its wear and erosion resistance. Although there are several studies on the duplex-surfacetreated AISI H13 hot work tool steel [11, 26-28], only a few limited studies were found related to duplex-surfacetreated QRO 90 Supreme hot work tool steel [29, 30]. Therefore, the aim of the current study is to investigate the effect of duplex surface treatments on hydro-abrasive erosion performance of QRO 90 Supreme steel by means of a specifically designed hydro-abrasive erosion test rig. Within the scope of this study, CrN and TiAlN coatings, which are widely used in commercial practical applications and can be alternative of each other, were chosen as the nitride coatings to be used in the duplex surface treatment.

\section{Experimental procedure}

QRO 90 Supreme hot work tool steel was used in this study. Its chemical composition is listed in table 1 . The erosion test specimens seen in figure 1a were machined from the as-received steel and subsequently ground down to 1200 grit with $\mathrm{SiC}$ emery papers. These specimens were then austenitized at $1050^{\circ} \mathrm{C}$ for a soaking period of $75 \mathrm{~min}$ and quenched in nitrogen atmosphere at 4 bar, followed by tempering in a furnace gradually at $605^{\circ} \mathrm{C}$ for $2 \mathrm{~h}$ and at $560^{\circ} \mathrm{C}$ for $4 \mathrm{~h}$. Before the plasma nitriding, the passive film on the surface of the specimens was removed by hydrogen sputtering at $430^{\circ} \mathrm{C}$ for $45 \mathrm{~min}$. A nitrogen and hydrogen mixture gas of $80 \% \mathrm{~N}_{2}-20 \% \mathrm{H}_{2}$ was used in the plasma nitriding processes. Plasma nitriding was performed with a commercial plasma nitriding furnace at $500^{\circ} \mathrm{C}$ for $10 \mathrm{~h}$ at a pressure of $250 \mathrm{kPa}$. After nitriding, the samples were
Table 1. The chemical composition (wt\%) of QRO 90 Supreme tool steel used in this investigation.

\begin{tabular}{lccccccc}
\hline Steel & $\mathrm{C}$ & $\mathrm{Mn}$ & $\mathrm{Si}$ & $\mathrm{Cr}$ & $\mathrm{Mo}$ & $\mathrm{V}$ & $\mathrm{Fe}$ \\
\hline $\begin{array}{l}\text { QRO 90 } \\
\text { Supreme }\end{array}$ & 0.38 & 0.75 & 0.30 & 2.60 & 2.30 & 0.90 & Balance \\
\hline
\end{tabular}

cooled down to room temperature in nitrogen gas flow. Before coating deposition on the plasma-nitrided specimens, the thin compound layer was removed to obtain a good coating adhesion and to avoid poor mechanical properties of this layer. The TiAlN and $\mathrm{CrN}$ thin films were deposited on the plasma-nitrided specimens by a PVD cathodic arc process. The coating deposition processes were carried out at $500^{\circ} \mathrm{C}$ for $6 \mathrm{~h}$ for TiAlN coatings, and at $440^{\circ} \mathrm{C}$ for $2.5 \mathrm{~h}$ for $\mathrm{CrN}$ coatings. It should also be noted that before TiAlN deposition process, a Ti layer was deposited to the specimens to ensure high adhesion strength of the TiAlN coating. The details of the produced specimens are seen in table 2 . The treated specimens were sectioned using an electrical discharge machine for the crosssectional study. Thereafter, the cut sections were mounted in bakelite and then the mounted specimens were ground manually using SiC emery papers of $200,400,600,800$, 1000 and 1200 grit sizes. Subsequently, the specimens were mirror polished successively through $1 \mu \mathrm{m}$ diamond paste on a cloth polishing wheel machine. Specimens were then washed and blow dried before being examined. Mirrorpolished specimens were characterized by optical microscopy and scanning electron microscopy (SEM) as well as energy-dispersive X-ray spectrometry (EDS) after etching in $4 \%$ Nital. Vickers microhardness measurements were carried out with a $25 \mathrm{~g}$ load for $10 \mathrm{~s}$. The surface roughness values in $R_{\mathrm{a}}$ scale of the specimens were measured on a TR200 Surface Roughness Tester that had a tracking length of $5 \mathrm{~mm}$ and least count of $0.001 \mu \mathrm{m}$.

A specially designed erosion test set-up was used to investigate the hydro-abrasive erosion performance of the asreceived and treated specimens (figure $1 \mathrm{~b}$ ). In the erosion tests, the specimens were rotated (specimen rotation method). The hydro-abrasive erosion medium was prepared with distilled water and ceramic abrasive particles. The sizes and shape of the ceramic abrasive particles used in this investigation are shown schematically in figure 1c. All experimental conditions, such as concentration, average ceramic abrasive particle size and rotational speed (53 rpm), were held constant during erosion test. The eroded specimens were taken out at $2 \mathrm{~h}$ intervals up to $24 \mathrm{~h}$ and then at $24 \mathrm{~h}$ intervals up to $96 \mathrm{~h}$ from the specimen holder disc. These specimens were ultrasonically cleaned in alcohol and dried with an air blower to measure the mass loss. The mass loss was measured using a precision electronic balance having $0.1 \mathrm{mg}$ accuracy. The eroded surface of the specimens was also observed and analysed by optical microscopy. 




(a)

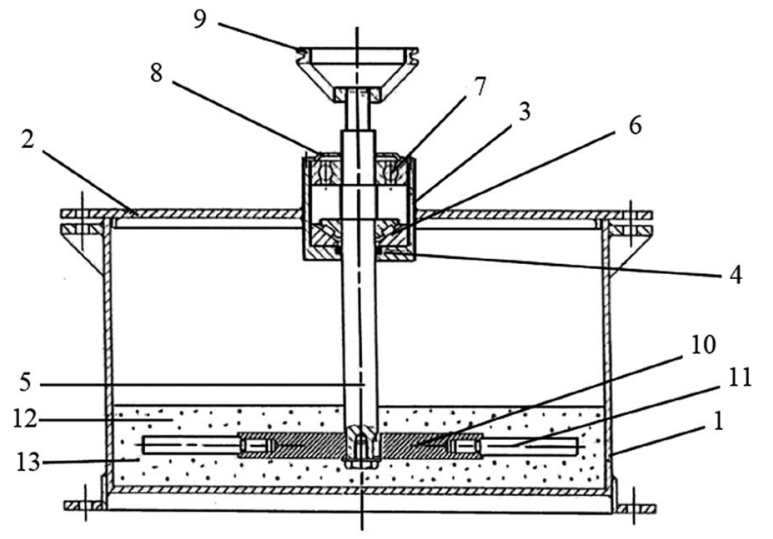

(b)

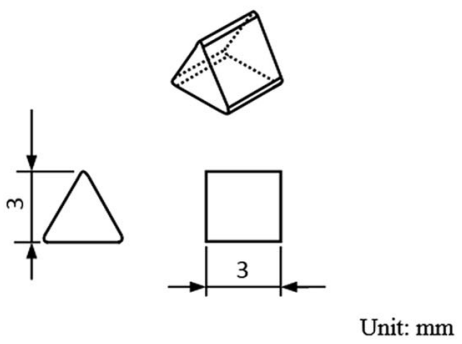

(c)

Figure 1. (a) The specimens used for the erosion test in this study, (b) The construction details of the hydro-abrasive erosion test set-up used for current investigation ((1) cylindrical test tank, (2) cover, (3) bearing, (4) oil seal, (5) shaft, (6) conical roller bearing, (7) roller bearing, (8) cover of the bearing, (9) pulley, (10) specimen holder disc, (11) specimen, (12) distilled water and (13) ceramic abrasive particles) [11,31] and (c) schematic sketch of the ceramic abrasive particles used in the hydro-abrasive erosion test [11].

Table 2. The test specimens investigated in this study.

\begin{tabular}{lcccc}
\hline Specimen & Tempering & $\begin{array}{c}\text { Plasma } \\
\text { nitriding }\end{array}$ & $\begin{array}{c}\text { CrN } \\
\text { coating }\end{array}$ & $\begin{array}{c}\text { TiAlN } \\
\text { coating }\end{array}$ \\
\hline $\begin{array}{l}\text { Q00 (as- } \\
\text { received) }\end{array}$ & - & - & - & - \\
Q10 & + & - & - & - \\
Q20 & + & + & - & - \\
Q21 & + & + & + & - \\
Q22 & + & + & - & + \\
\hline
\end{tabular}

+ done, - not done.

\section{Results and discussion}

\subsection{Microstructural characterization}

The microstructure of the plasma-nitrided specimens consists of three distinct layers (figure 2): a 3- $\mu$ m-thick compound layer (the upper layer), which is also called "white layer", a $120 \mu \mathrm{m}$ thick diffusion zone and the substrate. The compound layer consists of two iron nitride phases: $\varepsilon$-nitride $\left(\mathrm{Fe}_{2-3} \mathrm{~N}\right)$ and $\gamma^{\prime}$-nitride $\left(\mathrm{Fe}_{4} \mathrm{~N}\right)$. Wen [32] reported that these iron nitride phases within the compound layer were responsible for the good tribological and anti-corrosive properties of the surface. The diffusion zone immediately below the compound layer is a region characterized by fine alloy carbides in $\alpha-\mathrm{Fe}(\mathrm{C}, \mathrm{N})$ matrix.

The EDS measurements confirm the compositional features of these layers, showing higher nitrogen in the compound layer and lower nitrogen in the diffusion zone (figure 2). The substrate contains no nitrogen (figure 2). The cross-sectional views of the duplex-treated specimens can be seen in figures 3 and 4, showing distinctly the PVD coating layer and the plasma-nitrided diffusion zone.

The produced thin films are dense and nonporous, and the interfaces between coating and plasma-nitrided layer are defect free. The average $\mathrm{CrN}$ layer thickness is $2.4 \mu \mathrm{m}$ (figure 3). In figure 4 , the quite thin $\mathrm{Ti}$ interlayer, which is roughly $0.25 \mu \mathrm{m}$, is also seen on the TiAlN-deposited specimen. The average TiAlN layer thickness is roughly $4.15 \mu \mathrm{m}$. The EDS spectrums taken at a spot on the coatings and plasma-nitrided layers confirm the compositional features of these layers (figures 3 and 4). However, the nitrogen content is higher in the diffusion zone of the duplex-treated specimens than the plasma-nitrided specimen. This is associated with the extra nitrogen diffusion into this zone during the PVD processes at elevated temperatures. 
(a)

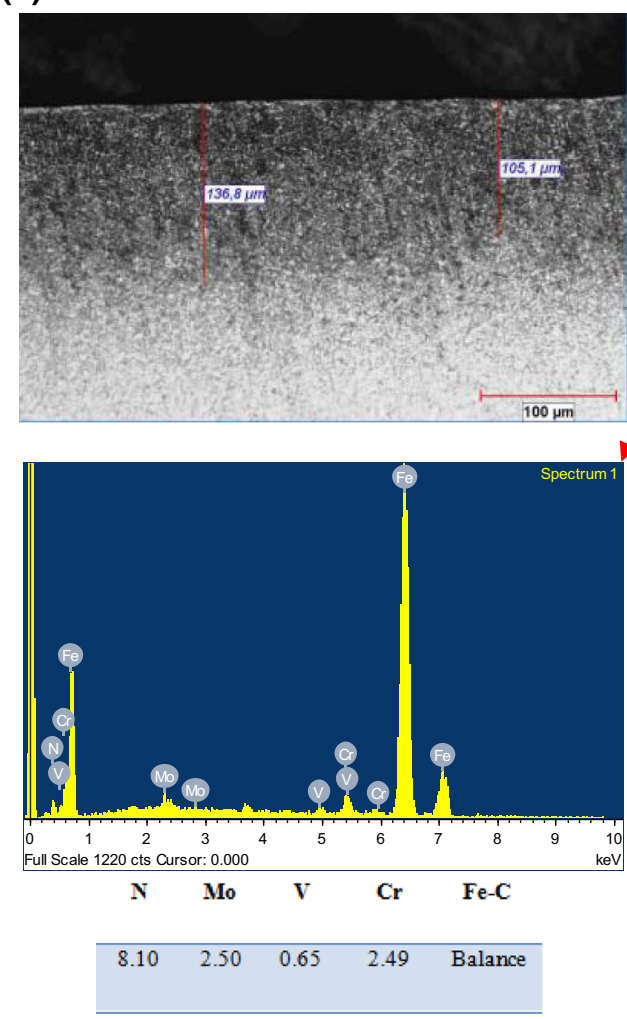

(b)

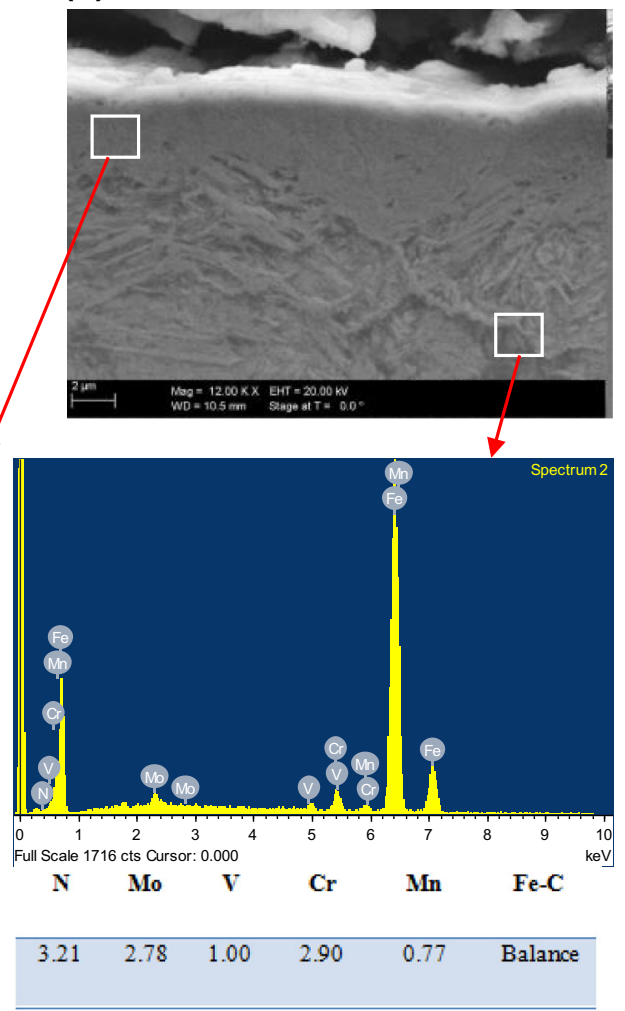

(c)

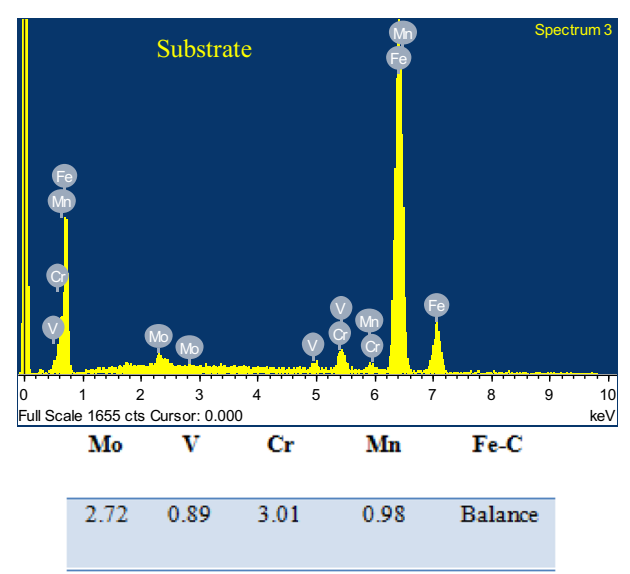

Figure 2. (a) Optical micrograph, (b) SEM image along with EDS analyses and (c) substrate EDS analysis of the plasma-nitrided specimen.

\subsection{Microhardness and surface roughness}

The average surface hardness values of the produced specimens can be seen in figure 5. The surface hardness of the as-received QRO 90 Supreme steel was $216 \mathrm{HV}_{0.025}$. Tempering process leading to the formation of tempered martensite increased the surface hardness of the as-received specimens to $578 \mathrm{HV}_{0.025}$. The hardness on the surface of plasma-nitrided specimen, where the compound layer was formed, attained a value of approximately $1092 \mathrm{HV}_{0.025}$, which is increased in comparison with that of the as-received and tempered specimens by a factor of approximately 5.1 and 1.9 , respectively. The hardness (1092 $\mathrm{HV}_{0.025}$ ) of the plasma-nitrided specimen decreased gradually with increasing distance from the surface and reached about $575 \mathrm{HV}_{0.025}$ at the substrate (figure 6). This can be attributed to the nitrogen concentration from the surface to the substrate [33-35]. The compound layer is extremely hard but very brittle, and hence it easily fails in service [36]. It should also be noted that any softening phenomenon was not observed in the substrate of the plasma-nitrided specimen during the nitriding process. Similarly, any softening phenomenon in the substrate of the 


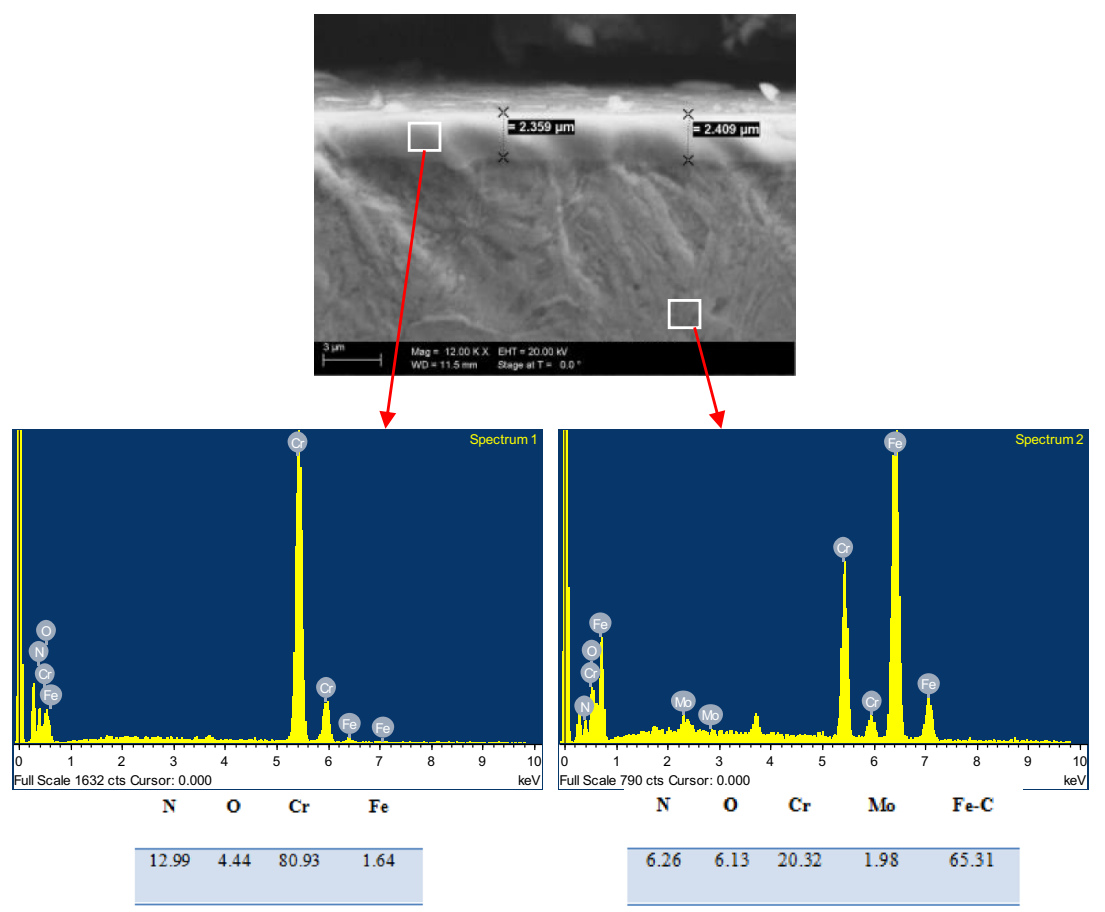

Figure 3. SEM image of CrN-coated specimen along with EDS analyses of CrN layer and plasma-nitrided diffusion zone.

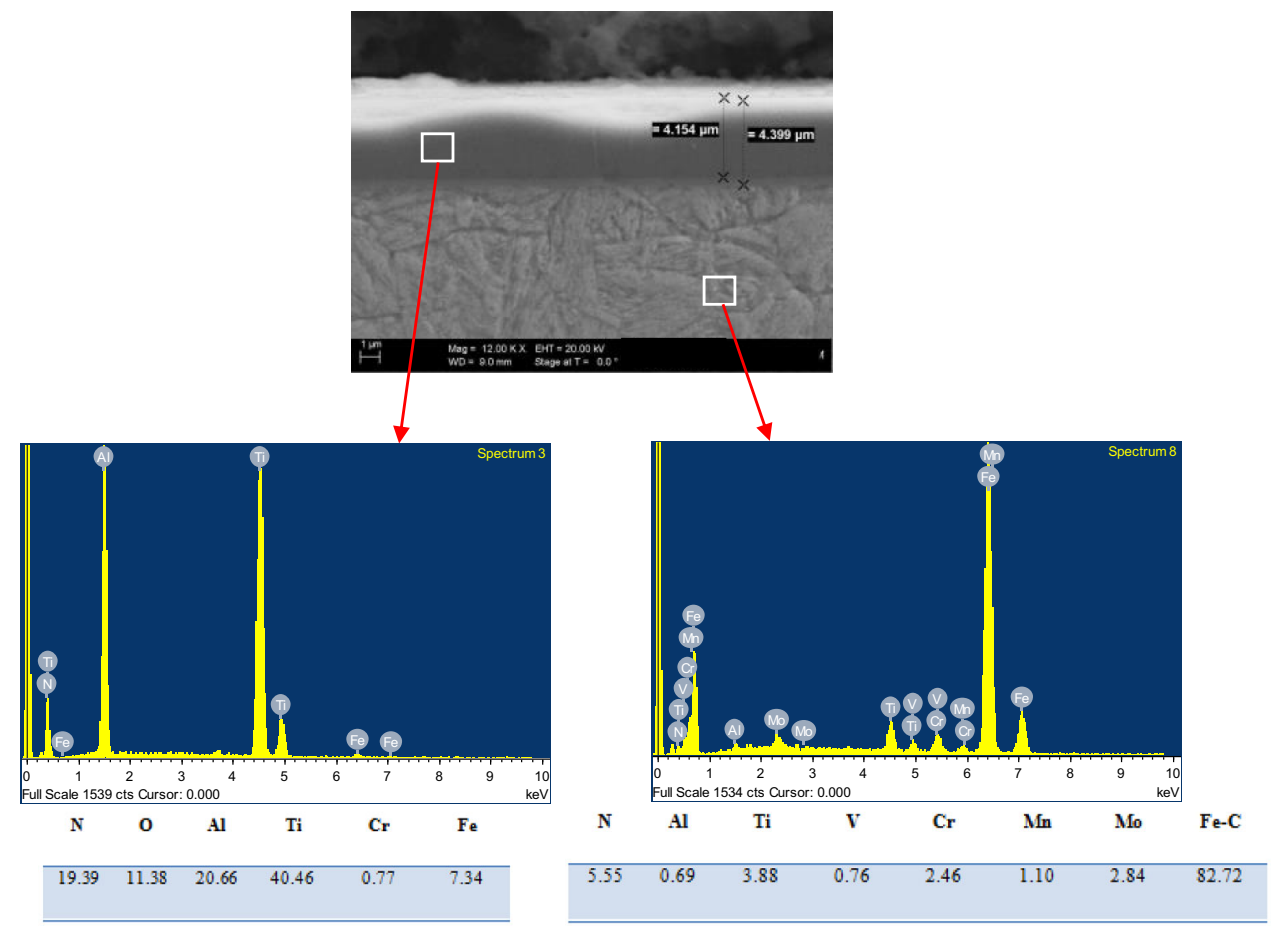

Figure 4. SEM image of TiAlN-coated specimen along with EDS analyses of TiAlN layer and plasma-nitrided diffusion zone.

duplex-treated specimens did not occur during PVD depositions. The deposition of $\mathrm{CrN}$ and TiAlN thin films significantly increased the surface hardness of the plasma- nitrided specimens. The average surface hardness value reached $3578 \mathrm{HV}_{0.025}$ through TiAlN thin film deposition onto the plasma-nitrided specimen. On the other hand, the 


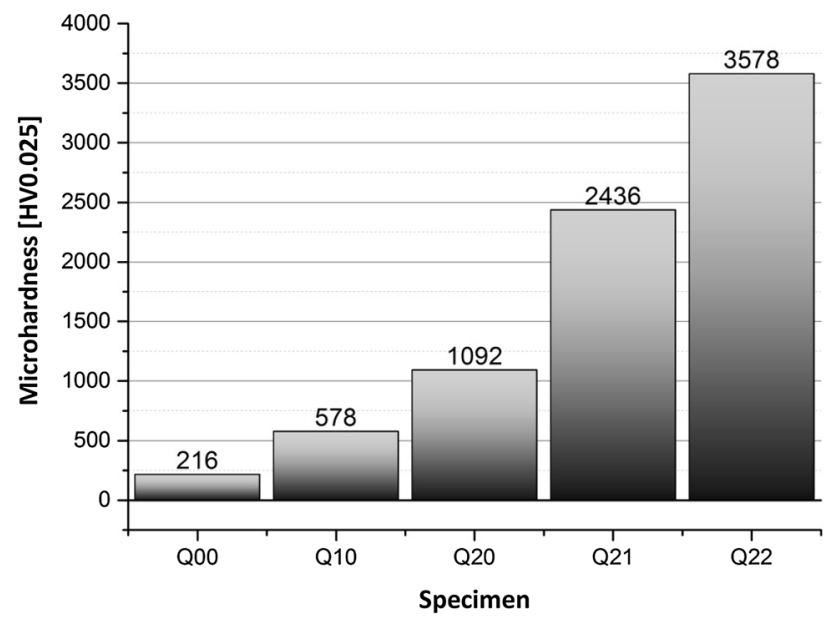

Figure 5. The average surface hardness of the tested specimens (see table 2 for the specimen codes).

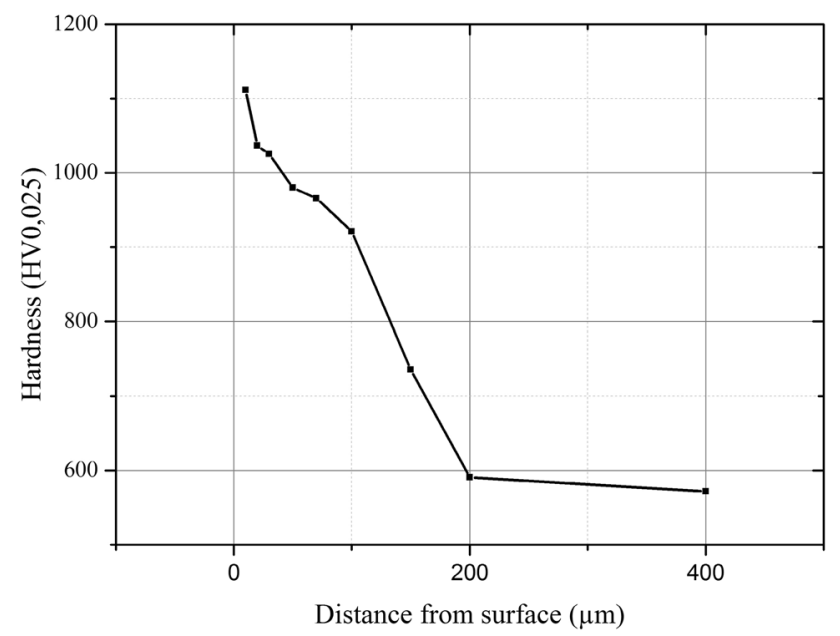

Figure 6. Microhardness profile of the plasma-nitrided specimen.

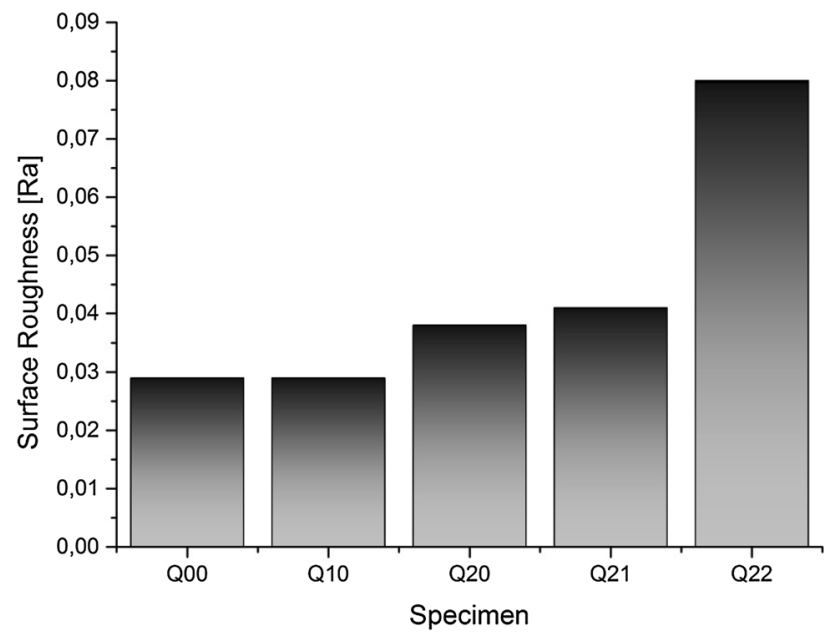

Figure 7. Surface roughness of the tested specimens before the erosion tests (see table 2 for the specimen codes).

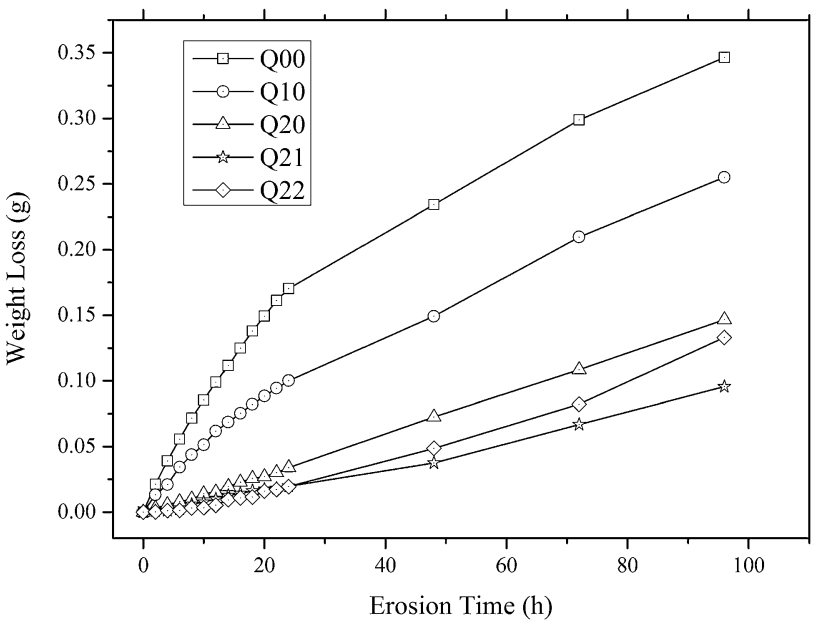

Figure 8. Cumulative mass losses versus erosion time for the investigated specimens (see table 2 for the specimen codes).

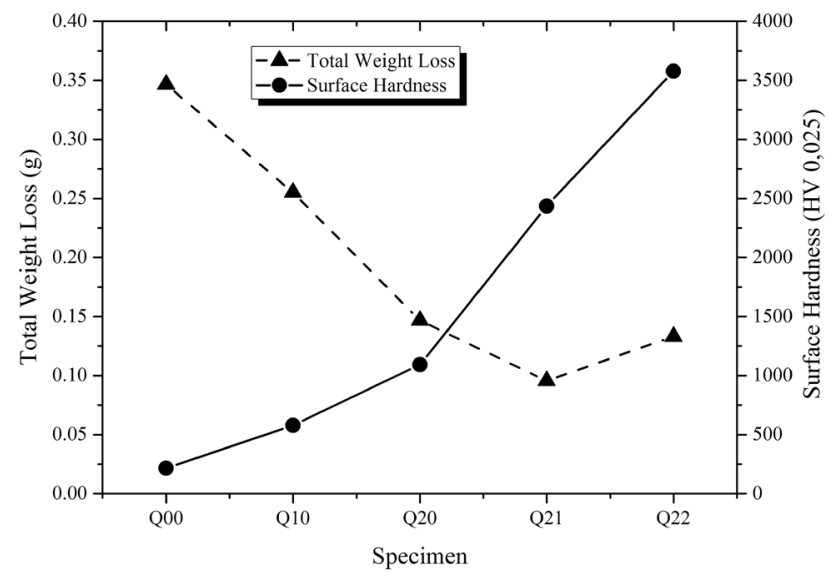

Figure 9. The total mass loss of the specimens versus surface hardness (see table 2 for the specimen codes).

Table 3. Erosion resistances of the specimens (see table 2 for the specimen codes).

\begin{tabular}{lccccc}
\hline Test specimen & Q00 & Q10 & Q20 & Q21 & Q22 \\
\hline Erosion resistance $\left[\mathrm{g}^{-1}\right]$ & 2.89 & 3.92 & 6.82 & 10.46 & 7.51 \\
\hline
\end{tabular}

surface hardness of the duplex-surface-treated specimen with $\mathrm{CrN}$ deposition was $2436 \mathrm{HV}_{0.025}$.

The surface roughness is one of the most important factors that determine the erosion or wear characteristics of the steels. The plasma nitriding process increased the surface roughness of the tempered specimen from 0.029 to $0.038 \mu \mathrm{m}$ owing to the formation of the complex nitrides on the treated surface (figure 7). As is obvious from the data illustrated in figure 7 , the surfaces have become rougher as a consequence of duplex surface treatments: The duplex-treated specimen with TiAlN coating had 
significantly higher increase in $\mathrm{Ra}$ values in comparison with the duplex-treated specimen with $\mathrm{CrN}$ coating. This may be attributed to more effective preferential crystallographic orientation in some directions.

\subsection{Hydro-abrasive erosion performance}

The erosion rates of the plasma-nitrided and duplex-treated specimens were almost stable during the test, implying a steady state erosion damage, while the erosion rates for asreceived and tempered specimens were initially higher and then decreased (figure 8). The highest mass losses were obtained for the as-received specimen and tempered specimen. This is clearly associated with the lower surface hardness values of these specimens (figure 9). The plasmanitrided specimen showed significantly lower mass loss than the as-received and tempered specimens (figure 8). The results at the end of $96 \mathrm{~h}$ showed that the erosion loss of the as-received QRO 90 Supreme tool steel decreased by $60 \%$ as a result of plasma nitriding process. This can be attributed to the formation of complex hard nitriding structures, such as iron, chromium and vanadium nitrides, in the hardened layer. On the other hand, mass losses under the investigated tribological conditions were significantly lower for the duplex-treated specimens than the other specimens. The CrN-coated specimens displayed a mass loss that was approximately 3.6-fold lower than the asreceived material while the TiAlN-coated specimens showed a mass loss that was 2.6-fold lower than the asreceived material. The erosion resistances of the specimens after a 96-h erosive test are given in table 3 . The erosion resistance of $\mathrm{CrN}$-coated specimens was increased by a factor of 3.6 and 1.5 compared with that of the as-received specimens and plasma-nitrided specimens, respectively. This indicated that duplex treatments were useful to develop erosion-resistance in the QRO 90 Supreme tool steel.

The total mass losses of the specimens versus surface hardness is shown in figure 9. In general, higher surface hardness resulted in lower mass loss. However, the mass loss of the TiAlN-coated specimen having the highest surface hardness was higher than that of the CrN-coated specimen. This may be attributed to low adherence ability of the TiAlN coating to the plasma-nitrided layer and harder and more brittle manner of the TiAlN coating. Tutar et al [11] also reported similar results for the duplex-treated AISI H13 tool steel. Additionally, the initial surface roughness of TiAlN-coated specimens was significantly

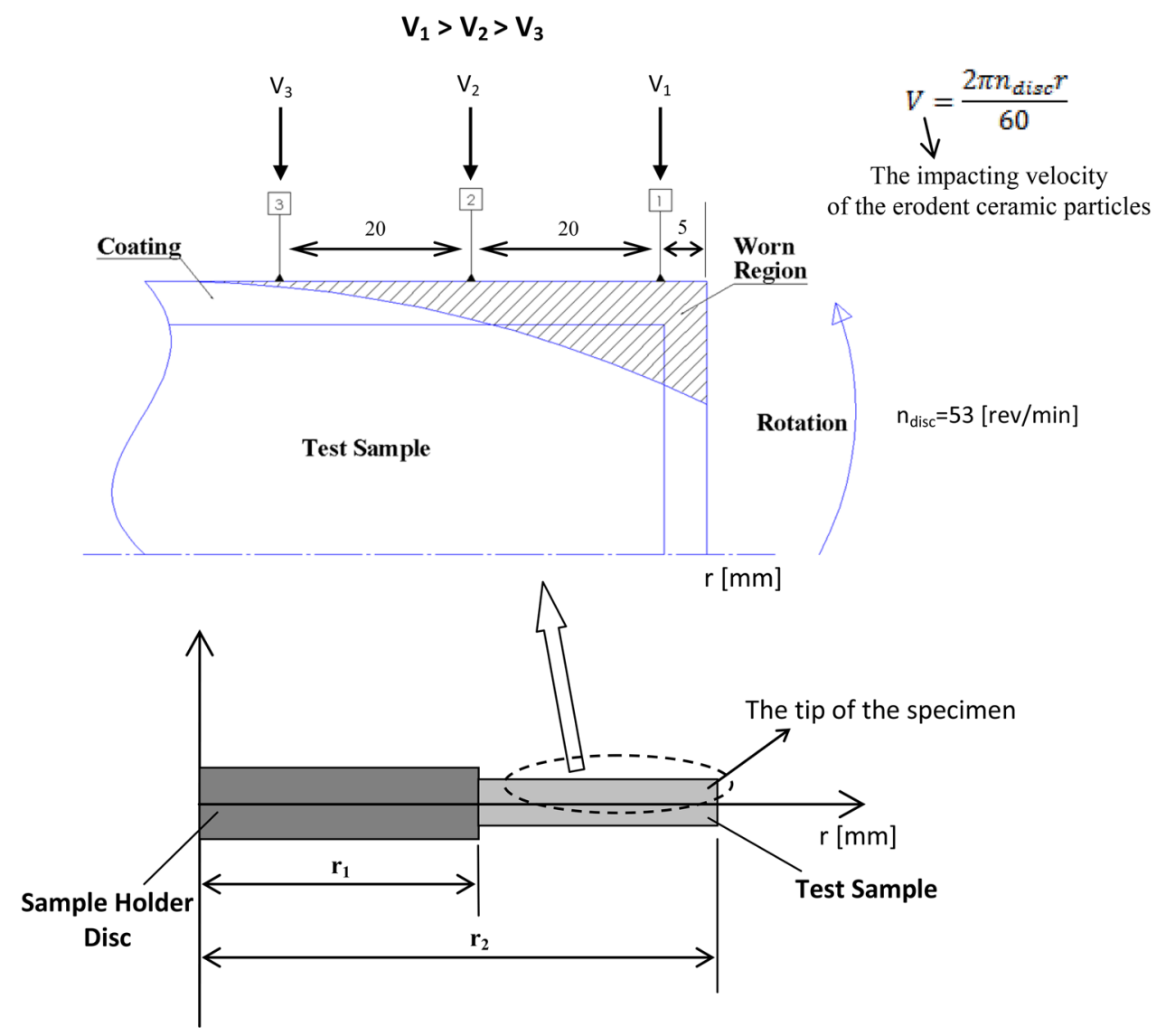

Figure 10. A schematic representation of the severity of erosive wear on the numbered regions along the specimens. 
higher than that of CrN-coated specimen. This may establish a number of sites on the surface, which are more easily sheared off by the abrasive hard particles.

Erosive wear becomes more effective with the increase in the velocity of impinging erodent particles $[2,10,37,38]$. The highest impacting velocities of the erodent ceramic particles to the specimens are near the tip of the specimens in this wear test system (figure 10).
Therefore, the highest erosion loss was observed near the tip of the specimens in this study. The material removal mechanism by hydro-abrasive erosive wear depends upon the mechanical properties of the target material and the erodent striking angle to the target surface $[2,39]$. Due to the rotation of the specimens in this tribological system, the erodent ceramic particles impinged the curved surface of the specimen at various interaction angles (completely (a)

(b)
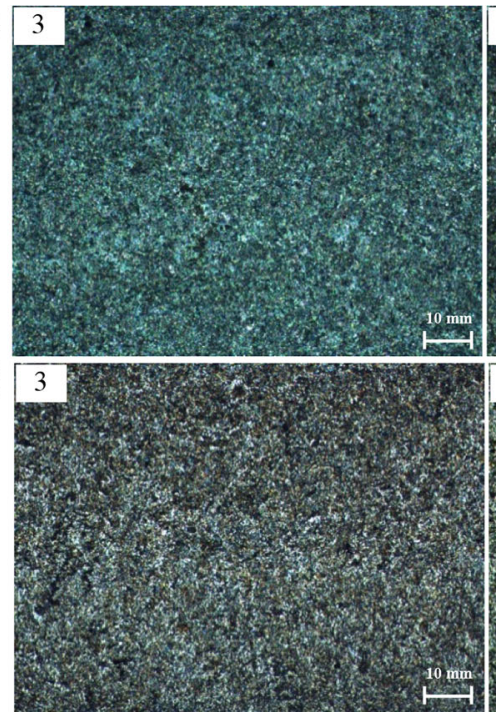

(c)

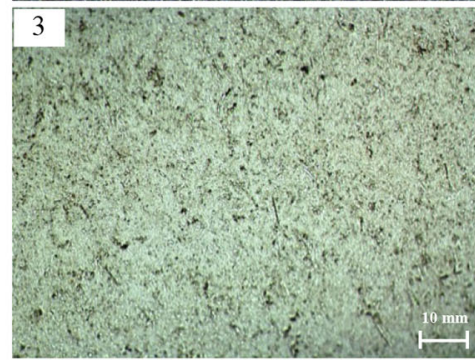

(d)

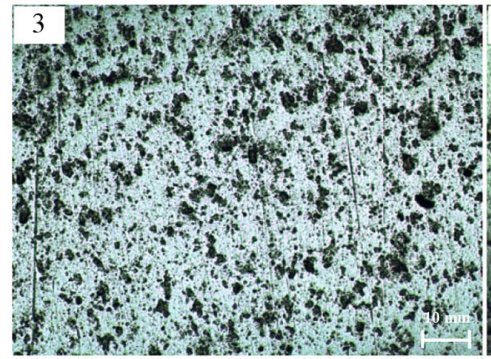

(e)

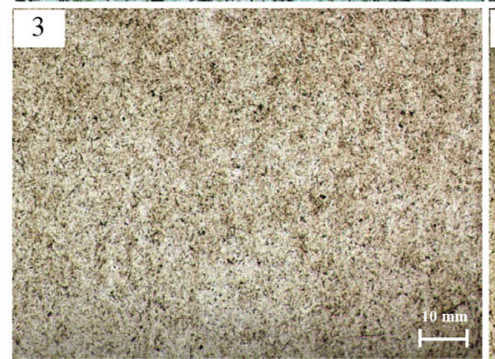

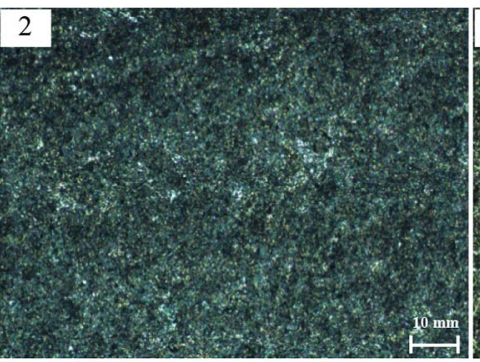
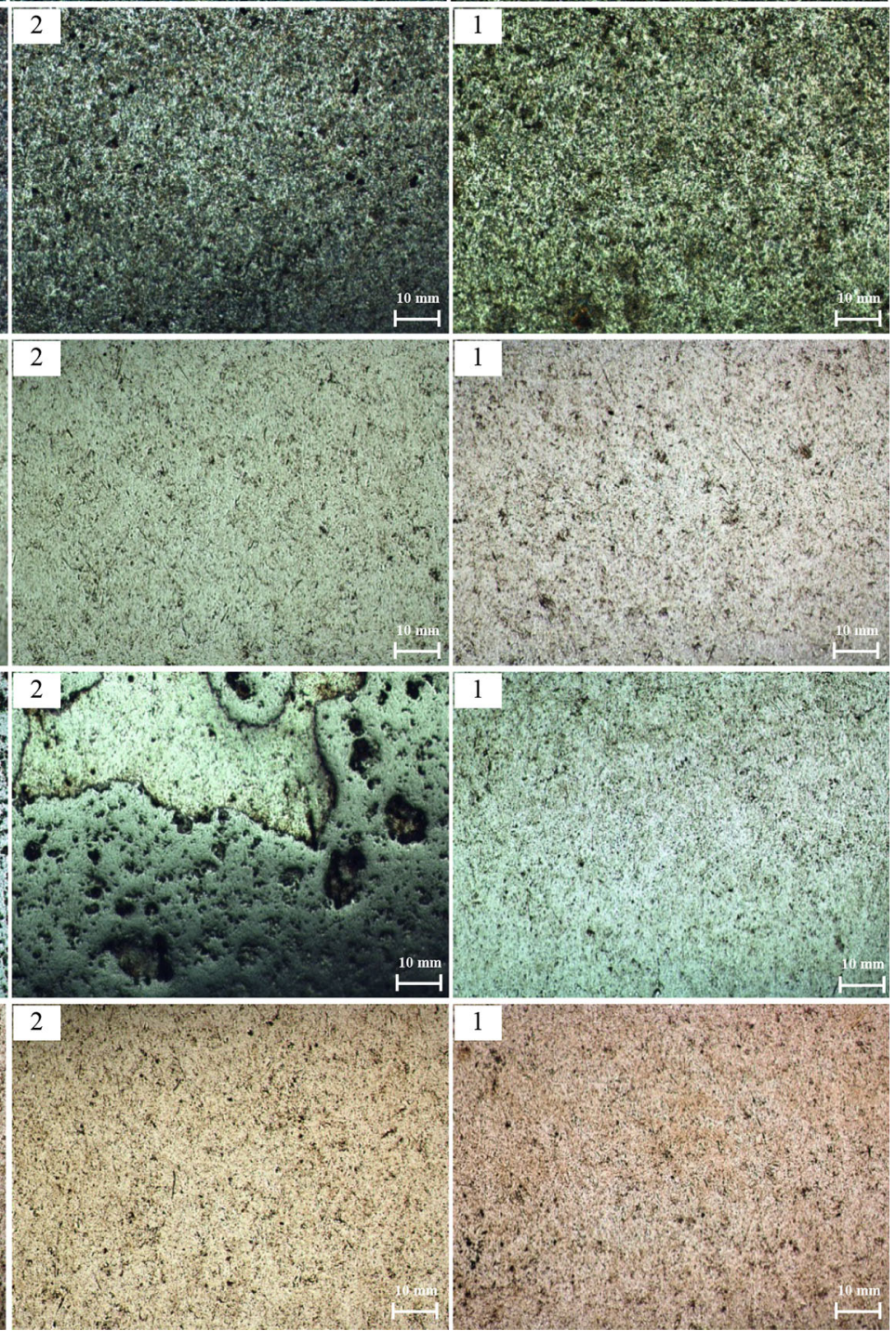

Figure 11. Optical microscopy images of eroded surfaces of the specimens corresponding to the numbered regions marked in figure 10: (a) Q00, (b) Q10, (c) Q20, (d) Q21 and (e) Q22 (see table 2 for the specimen codes). 
random), ranging from $-90^{\circ}$ to $+90^{\circ}$. Tangential interaction has a cutting or plowing effect (abrasive wear) at the surface, while normal interaction causes the material to fail by fatigue or brittle cracking, particularly in brittle materials (impact wear). The optical microscopy features of worn surfaces of the specimens are given in figure 11 . Topographical images were taken in line corresponding to around $90^{\circ}$ (normal interaction). It can be observed that the surfaces of the as-received and tempered specimens were severely deformed in all three regions during the erosion tests due to the low surface hardness (figure $11 \mathrm{a}, \mathrm{b}$ ). The erosion traces developed on these specimens were wider and deeper. The optical characteristics of these specimens show impact traces, repetitive plastic deformation or cutting and plowing, which were created by the ceramic abrasive particles. Thus, two material removal mechanisms occurred in these specimens simultaneously, i.e., plowing abrasion and indentation, including mainly a ductile type of material removal. Bhandari et al [40] also observed similar characteristics during solid particle erosion of ferrous materials. The erosion traces of the plasma-nitrided specimen were shallower and more superficial than that of asreceived and tempered ones (figure 11c). The mechanism of material removal observed in plasma-nitrided specimens can be evaluated as plowing and fatigue (ductile manner with a partial brittle cracking). In the $\mathrm{CrN}$-coated specimen (figure 11d), $\mathrm{CrN}$ coating layer was not observed in region (1) after erosion tests, while the partially eroded $\mathrm{CrN}$ layer with the large brittle impact traces was observed in region (2). Region (3) exhibited the evident small brittle impact traces on CrN coating layer (figure 11d). In the TiAlNcoated specimen, the coating layer was wholly eroded in all regions (figure 11e). The $\mathrm{CrN}$ and TiAlN coatings were substantially eroded by a combined mechanism of coating exfoliation and brittle manner fracture, removing as fragments of the coating (figure 11). This may be due to fatigue cracking process caused by the impinging ceramic particles at nearly normal interaction $[19,41]$.

\section{Conclusions}

On the basis of the obtained results, the main conclusions can be drawn as follows:

1. The surface hardness of the plasma-nitrided QRO 90 Supreme tool steel was increased by a factor of approximately 5.1 and 1.9 in comparison with that of the asreceived and tempered specimens, respectively. Any softening phenomenon did not occur in the substrate of the plasma-nitrided specimen. The surface layer hardness significantly increased with $\mathrm{CrN}$ and TiAlN thin films deposition onto the plasma-nitrided specimens. The average surface hardness was $3578 \mathrm{HV}_{0.025}$ in the TiAlN-coated specimens, which was approximately 17 -fold higher than that of the as-received specimens and over 3 -fold greater than that of the plasma-nitrided specimens. The average surface hardness of the $\mathrm{CrN}$-coated specimens was 2436 $\mathrm{HV}_{0.025}$, which was over 11-fold higher than that of the asreceived specimens and over 2-fold greater than that of the plasma-nitrided specimens.

2. The plasma nitriding and duplex surface treatments increased the surface roughness. In particular, the TiAlN thin film deposition onto the plasma-nitrided layer significantly increased the surface roughness by a factor of approximately 2.8 in comparison with that of the asreceived and tempered specimens.

3. The plasma nitriding process and the duplex surface treatments were found to be useful to enhance the hydroabrasive erosion resistance of QRO 90 Supreme steel. The increased surface hardness resulted in generally a higher erosion resistance for hydro-abrasive erosion tests. CrN-coated specimen exhibited the highest erosion resistance: The erosion resistance of $\mathrm{CrN}$-coated specimens was increased by a factor of 3.6 and 1.5 compared with that of the as-received specimens and plasmanitrided specimens, respectively.

4. Most of the wear losses in as-received and tempered QRO 90 Supreme tool steel occurred because of plowing abrasion and indentation, including a ductile type of material removal, whereas most of the wear losses in the duplex-surface-treated QRO 90 Supreme tool steel occurred because of brittle fracture phenomena induced by particles impinging. However, the plasma-nitrided QRO 90 Supreme tool steel showed a mixed behaviour of ductility and brittle failure during the hydro-abrasive erosion testing. In addition, the TiAlN-coated specimen, which had the highest surface hardness and highest surface roughness, exhibited more extensive brittle failure tendency as a result of hard erodent particle impact.

\section{References}

[1] Winkler K 2014 Hydro-abrasive erosion: problems and solutions. IOP Conf. Ser. Earth Environ. Sci. 22: 052022

[2] Goyal D K, Singh H, Kumar H and Sahni V 2012 Slurry erosive wear evaluation of HVOF-spray $\mathrm{Cr}_{2} \mathrm{O}_{3}$ coating on some turbine steels. J. Therm. Spray Technol. 21: 838-851

[3] Feng Z and Ball A 1999 The erosion of four materials using seven erodents-towards an understanding. Wear 233-235: 674-684

[4] Liebhard M and Levy A 1991 The effect of erodent particle characteristics on the erosion of metals. Wear 151: 381-390

[5] Sangal S, Singhal M K and Saini R P 2018 Hydro-abrasive erosion in hydro turbines: a review. Int. J. Green Energy 15: 232-253

[6] Truscott G F 1972 A literature survey on abrasive wear in hydraulic machinery. Wear 20: 29-50

[7] Padhy M K and Saini R P 2008 A review on silt erosion in hydro turbines. Renew. Sust. Energy Rev. 12: 1974-1987 
[8] Neopane H P, Dahlhaug O G and Cervantes M 2011 Sediment erosion in hydraulic turbines. Glob. J. Res. Eng. Mech. Mech. Eng. 11: 11

[9] Kulu P, Veinthal J, Koo H and Lille H 2000 Mechanism of abrasion erosion wear of thermal sprayed coatings. In: Proceedings of Conference EUROMAT 2000 on Advances in Mechanical Behaviour, Plasticity and Damage, Tours, France

[10] Kulu P and Halling J 1998 Recycled hard metal-base wear resistance composite coatings. J. Therm. Spray Technol. 7: 173-178

[11] Tutar M, Aydin H, Durmus A, Bayram A and Yigit K 2014 The hydro-abrasive erosion wear behavior of duplex-treated surfaces of AISI H13 tool steel. Sci. China Technol. Sci. 57: 1040-1051

[12] Wei C Y and Chen F S 2005 Characterization on multi-layer fabricated by TRD and plasma nitriding. Mater. Chem. Phys. 90: $178-184$

[13] Alsaran A, Çelik A, Çelik C and Efeoğlu I 2004 Optimization of coating parameters for duplex treated AISI 5140 steel. Mater. Sci. Eng. A 371: 141-148

[14] Batista J C A, Joseph M C, Godoy C and Matthews A 2001 Micro-abrasion wear testing of PVD TiN coatings on untreated and plasma nitrided AISI H13 steel. Wear 249: 971-979

[15] Hakami F, Heydarzadeh S M and Rasizadeh G J 2011 Duplex surface treatment of AISI 1045 steel via plasma nitriding of chromized layer. Thin Solid Films 519: 6792-6796

[16] King P C, Reynoldson R W, Brownrigg A and Long J M $2004 \mathrm{Cr}(\mathrm{N}, \mathrm{C})$ diffusion coating formation on pre-nitrocarburised H13 tool steel. Surf. Coat. Technol. 179: 18-26

[17] Taktak S, Ulker S, Gunes I and Yalcin Y 2008 Effect of $\mathrm{N}_{2}+$ $\mathrm{H}_{2}$ gas mixtures in plasma nitriding on tribological properties of duplex surface treated steels. Mater. Charact. 59: 1784-1791

[18] Taktak S, Ulker S and Gunes I 2008 High temperature wear and friction properties of duplex surface treated bearing steels. Surf. Coat. Technol. 202: 3367-3377

[19] Jianxin D, Fengfang W, Yunsong L, Youqiang X and Shipeng L 2012 Erosion wear of CrN, TiN, CrAlN, and TiAlN PVD nitride coatings. Int. J. Refract. Met. Hard Mater. 35: $10-16$

[20] Laguna-Camacho J R, Escalante-Martínez J E, Cruz-Vicencio R, Méndez-Méndez J V, Arzate-Vázquez I, HernándezRomero I and Vite-Torres M 2014 Solid particle erosion behaviour of TiN coating on AISI 4140 steel. J. Surf. Eng. Mater. Adv. Technol. 4: 1-8

[21] Cabo A, Brühl S P, Vaca L S, Charadia R and Dalibon E L 2010 Plasma nitriding of a precipitation hardening stainless steel to improve erosion and corrosion resistance. In: Proceedings of the 18th International Federation for Heat Treatment and Surface Engineering Congress (IFHTSE), pp. 5290-5298

[22] Hasan M I, Mohamed A H and Hashim A L 2015 A study of wear performance of hard coatings with plasma nitride and without plasma nitride of $\mathrm{H} 13$ die steel in aluminum casting. In: Proceedings of the First Babylon International Engineering Conference, Babylon University, Iraq

[23] Allenstein A N, Lepienski C M, Buschinelli A J A and Brunatto S F 2013 Plasma nitriding using high $\mathrm{H}_{2}$ content gas mixtures for a cavitation erosion resistant steel. Appl. Surf. Sci. 277: 15-24

[24] Panjan P, Čekada M, Kirn R and Soković M 2004 Improvement of die-casting tools with duplex treatment. Surf. Coat. Technol. 180-181: 561-565

[25] QRO 90 supreme hot work tool steel. http://www.uddeholm. hu/hungarian/files/QRO_en.pdf, accessed in January 2018

[26] Chang S H, Lin Y K and Huang K T 2012 Study on the thermal erosion, wear and corrosion behaviors of TiAlN/ oxynitriding duplex-treated AISI H13 alloy steel. Surf. Coat. Technol. 207: 571-578

[27] Chang S H, Huang K T and Wang Y H 2012 Effects of thermal erosion and wear resistance on AISI H13 tool steel by various surface treatments. Mater. Trans. 53: 745-751

[28] Navinsek B, Panjan P, Urankar I, Cvahte P and Gorenjak F 2001 Improvement of hot-working processes with PVD coatings and duplex treatment. Surf. Coat. Technol. 142-144: $1148-1154$

[29] Persson A, Bergstrom J and Hogmark S 2002 Influence of surface engineering on the performance of tool steels for die casting. In: Proceedings of the 6th International Tooling Conference, Karlstad, Sweden

[30] Persson A, Hogmark S and Bergstrom J 2005 Thermal fatigue cracking of surface engineered hot work tool steels. Surf. Coat. Technol. 191: 216-227

[31] Yigit K and Aydin H 2010 Hydro-abrasive erosion resistance of C45 steel in different heat-treated states on a designed hydro-abrasive wear test apparatus. Mater. Test. 52: 323-331

[32] Wen D C 2010 Erosion and wear behavior of nitrocarburized DC53 tool steel. Wear 268: 629-636

[33] Aydin H, Bayram A and Topcu S 2013 Effect of different nitriding processes on the friction coefficient of 304 austenitic and 420 martensitic stainless steels. Ind. Lubr. Tribol. 65: $27-36$

[34] Aydin H, Bayram A and Topcu S 2013 Friction characteristics of nitrided layers on AISI 430 ferritic stainless steel obtained by various nitriding processes. Mater. Sci. Medzg. 19: $19-24$

[35] Pinedo C E and Monteiro W A 2001 Surface hardening by plasma nitriding on high chromium alloy steel. J. Mater. Sci. Lett. 20: 147-149

[36] Vandendael I, Steenhaut O, Hubin A, Vereecken J, Prince P, Reniers F and Segato T 2004 AES analysis of nitride layers on steel with target factor analysis. Surf. Interface Anal. 30: 1093-1097

[37] Postlethwaite J and Nesic S 1993 Erosion in disturbed liquid/particle pipe flow: effects of flow geometry and particle surface roughness. Corrosion 49: 850-857

[38] Salama M M 2000 An alternative to API 14E erosional velocity limits for sand-laden fluids. J. Energy Resour. Technol. 122: 71-77

[39] Goyal D K, Singh H and Kumar H 2011 An overview of slurry erosion control by the application of high velocity oxy fuel sprayed coatings. J. Eng. Tribol. 255: 1092-1105

[40] Bhandari S, Singh H, Kumar H and Rastogi V 2012 Slurry erosion performance study of detonation gun-sprayed WC10Co-4Cr coatings on CF8M steel under hydro-accelerated conditions. J. Therm. Spray Technol. 21: 1054-1064

[41] Wheeler D W and Wood R J K 2005 Erosion of hard surface coatings for use in offshore gate valves. Wear 258: $526-536$ 